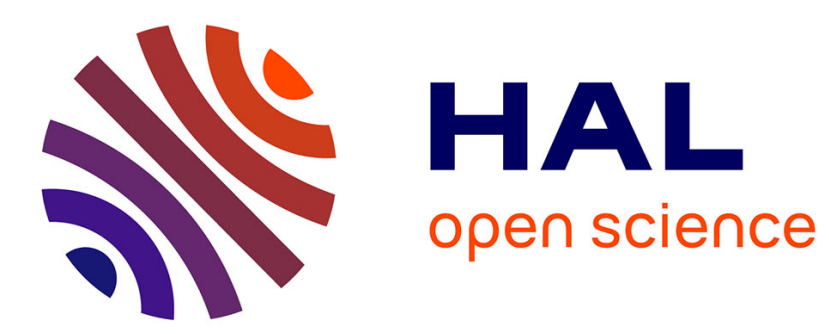

\title{
Microstructural analysis of Shanghai remolded clay during one-dimensional consolidation test
}

\author{
Ling Rong Kong, Hong Huang, Pierre-Yves Hicher, Dong Zhang
}

\section{To cite this version:}

Ling Rong Kong, Hong Huang, Pierre-Yves Hicher, Dong Zhang. Microstructural analysis of Shanghai remolded clay during one-dimensional consolidation test. Geomechanics and Geotechnics: From Micro to Macro, 2011, Shangai, China. hal-01633233

\section{HAL Id: hal-01633233 \\ https://hal.science/hal-01633233}

Submitted on 12 Nov 2017

HAL is a multi-disciplinary open access archive for the deposit and dissemination of scientific research documents, whether they are published or not. The documents may come from teaching and research institutions in France or abroad, or from public or private research centers.
L'archive ouverte pluridisciplinaire HAL, est destinée au dépôt et à la diffusion de documents scientifiques de niveau recherche, publiés ou non, émanant des établissements d'enseignement et de recherche français ou étrangers, des laboratoires publics ou privés. 


\title{
Microstructural analysis of Shanghai remolded clay during one-dimensional consolidation test
}

\author{
Ling Rong Kong \\ Shanghai Geotechnical Investigations \& Design Institute Co. Ltd., Shanghai, China \\ Hong Wei Huang \\ Department of Geotechnical Engineering, Tongji University, Shanghai, China \\ Pierre-Yves Hicher \\ Research Institute in Civil and Mechanical Engineering, Ecole Centrale de Nantes, France \\ Dong Mei Zhang \\ Department of Geotechnical Engineering, Tongji University, Shanghai, China
}

\begin{abstract}
The microstructure of soil has a significant influence on the mechanical behavior. In this paper, photos of Scanning Electron Microscope (SEM) are taken on Shanghai remolded clay samples under different consolidated pressures during onedimensional consolidation test. The evolutions of microstructure of remolded clay (including aggregate shape, aggregate mean surface and orientation distribution) from both horizontal cut plane and vertical cut plane of the specimen are analyzed and compared.
\end{abstract}

Keywords: microstructure, clay, consolidation test, SEM

\section{INTRODUCTION}

Shanghai clay is characterized with high water content, high void ratio, low shear strength, high compressibility and low permeability. Because of the economical boom in Shanghai, the clay deposits in Shanghai become more and more solicited by different constructions. In general, soil properties are decided by its macroscopic behavior which can be represented by its stress-strain relationship, which is lacking of considering the soil microstructure. The microstructure is an important aspect of soil. The microstructure during one-dimensional consolidation has been studied by Martin and Ladd [1975], Mcconnachie [1974], Matsuo [1977], Hicher et al. [2000] and etc.

For better understanding the shanghai clay behavior, in this paper remolded Shanghai soft clay specimens are studied by standard oedometer tests. The SEM observation is made on samples loaded at different stress levels. The quantitative analysis of the microstructure of Shanghai remolded clay are studied.

\section{SHANGHAI CLAY MICROSTRUCTURE PROPERTY}

In this paper, the soil samples are from Nanxiang-Baili Unistate of Metro 11. The depth is $8 \sim 8.5 \mathrm{~m}$. Physical properties of the selected soil are listed in Table 1. In order to investigate the deformation mechanism, three conventional oedometer tests were carried out for samples under 132, 264 and $800 \mathrm{kPa}$. 
Table 1. Physical properties of soil. ${ }^{5}$

\begin{tabular}{llllll}
\hline depth $/ \mathrm{m}$ & $e_{0}$ & $W / \%$ & $W_{\mathrm{L}} / \%$ & $W_{\mathrm{P}} / \%$ & $\gamma \mathrm{kg} / \mathrm{m}^{-3}$ \\
\hline $8 \sim 8.5$ & $1.12 \sim 1.16$ & $39.4 \sim 43.7$ & 51.6 & 25.8 & $1.71 \sim 1.74$ \\
\hline
\end{tabular}

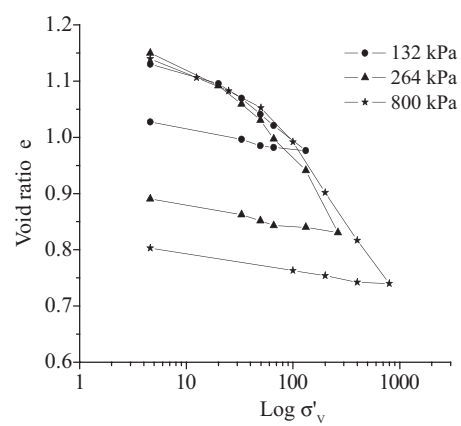

Figure 1. Compressive curves up to different consolidation pressures for remolded samples.

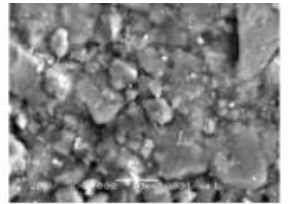

(a) Initial state

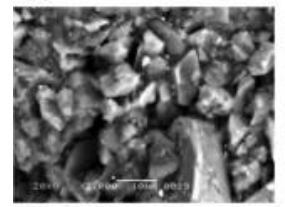

(e) Initial state

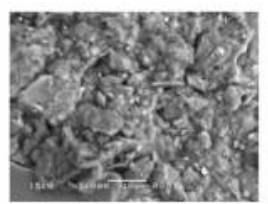

(b) $\sigma_{v}^{\prime}=132 \mathrm{kPa}$

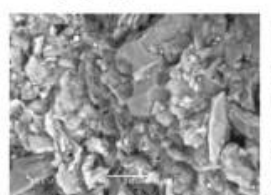

(f) $\sigma_{\mathrm{H}}{ }^{\prime}=132 \mathrm{kPa}$

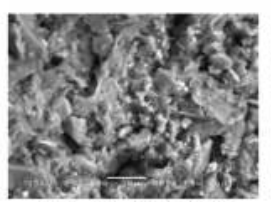

(c) $\sigma_{v}^{\prime}=264 \mathrm{kPa}$

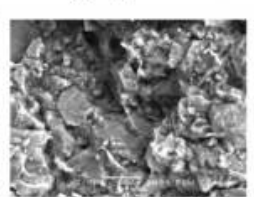

(g) $\sigma_{\mathrm{H}}{ }^{\prime}=264 \mathrm{kPa}$

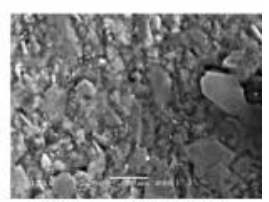

(d) $\sigma_{\mathrm{v}}^{\prime}=800 \mathrm{kPa}$

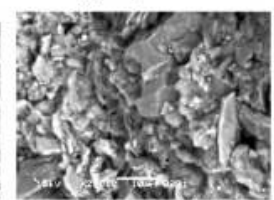

(h) $\sigma_{\mathrm{H}}{ }^{\prime}=800 \mathrm{kPa}$

Figure 2. Remolded specimen SEM photos under different consolidation pressure (a-d for vertical planes and $\mathrm{e}-\mathrm{h}$ for horizontal planes).

Observations for both horizontal planes and vertical planes of shanghai remolded clay specimens under different consolidation pressures are shown in Fig. 2. The particles of remolded specimen are dominant on aggregates. The void between particles exists. The particle size with the diameter is distributed between $0 \sim 10 \mu \mathrm{m}$, but the diameter of large formed aggregates is more than $20 \mu \mathrm{m}$. The form of aggregates is associated by face to face. Increasing the consolidation pressure, the particles and aggregates become dense for both horizontal and vertical planes. The aggregates are reduced into small-size aggregates when remolded. As the same time, there are some particles and small aggregates move to adjacent particles and aggregates to form new big aggregates. In addition, the particles and aggregates rearrange to be privilege on the direction under remolded force, where the orientation in vertical plane is more obvious than the horizontal plane.

\section{QUANTITATIVE ANALYSIS OF SHANGHAI REMOLDED CLAY STRUCTURE EVOLUTION}

The SEM photos can be used to quantitatively measure the evolution of clay structure elements, mainly of aggregates and single particles. 
The analysis is based on the following parameters:

1. Particle orientation $F(a)$.

$$
F_{i}(\alpha)=\frac{m}{M} \times 100 \%
$$

where $F_{i}(\alpha)$ means one direction distribution frequency, in each SEM photo, the plane was divided into a given number quadrants, each of them equal to $15^{\circ} ; \mathrm{m}$ means the particle numbers in the $i$ th quadrant; $M$ means the total numbers in one SEM photo. In order to study particle orientation, the rose diagrams from SEM photos was carried out.

2. $I$ shape index, which is the value of the ratio between the long axis A and the short axis $\mathrm{B}$ of the individual particle or individual aggregate (the particle or aggregate is considered as an ellipse). If $I_{s}$ equal to 1 , it means that the particle or aggregate is round or square.

3. $S_{\text {mean }}$ the mean surface:

$$
S_{\text {mean }}=\pi A B / 2
$$

\subsection{Particle orientation analysis}

For Shanghai remolded clay, shown in Fig. 3(a), we could see that the particles or aggregates distributed in every quadrant for both horizontal and vertical planes, but the particles or aggregates have two peak values: $0^{\circ} \sim 15^{\circ}$ and $75^{\circ} \sim 90^{\circ}$. The particles or aggregates are composed of mainly frames for both in horizontal and vertical planes.

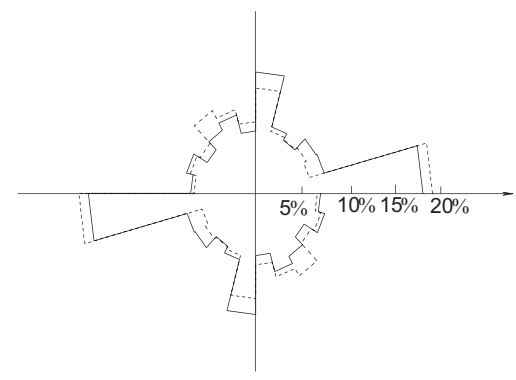

(a) $0 \mathrm{kPa}$

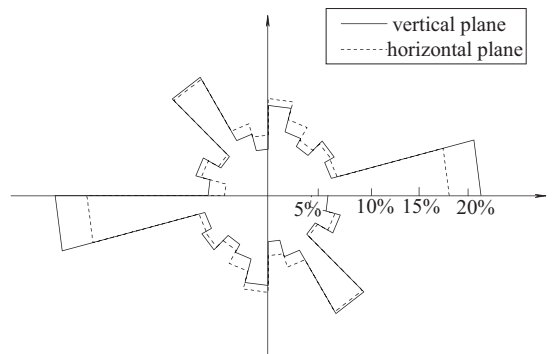

(b) $264 \mathrm{kPa}$

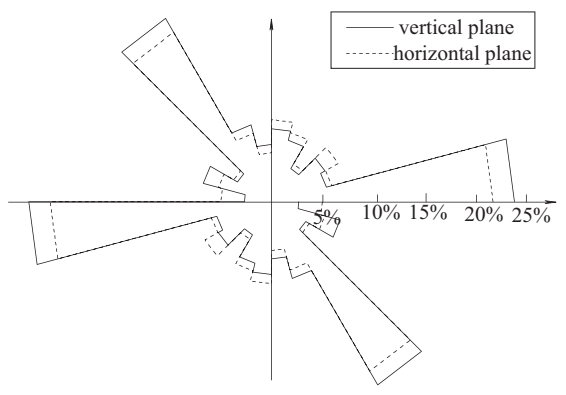

(c) $800 \mathrm{kPa}$

Figure 3. Rose diagrams of aggregate orientation of Shanghai remolded clayunder different consolidation pressure. 
The particle orientation is obviously changing with the increasing of consolidation pressure. For example, in Fig. 3(b) when the consolidation pressure is $264 \mathrm{kPa}$, there are more particles in $0^{\circ} \sim 15^{\circ}$ and $120^{\circ} \sim 135^{\circ}$, but less particles in $75^{\circ} \sim 90^{\circ}$. This means that the particles rotate when increasing the consolidation pressure, which results in particles existing in some privileged directions. The phenomenon is more remarkable for $800 \mathrm{kPa}$. It can be concluded that more anisotropy due to reorientation of particle under higher consolidation pressure.

\subsection{Particle shape index analysis}

The shape index histograms of aggregates for Shanghai remolded clay were shown in Fig. 4. The shape index dominant on 1.5 2 for horizontal plane shows that the particle shape is mainly ellipse; the shape index dominant on $1.5 \sim 2$ and $2.5 \sim 3$ for vertical plane shows that the particle shape is more ellipse compared with horizontal plane. The particle shape is obviously ellipse for both horizontal and vertical planes with the increasing of consolidation pressures. The value of shape index is $2.5 \sim 3$. When the consolidation pressure is $800 \mathrm{kPa}$, the phenomenon is more remarkable. There are more ellipse shaped aggregates and less other shaped aggregates. During the one-dimensional compression, aggregates slap and change their shapes, which is in accordance with the anisotropy of the aggregates.

\subsection{Particle mean surface analysis}

The particle mean surface of aggregate for Shanghai remolded clay is shown in Fig. 5. The particle mean surface or equal diameter decreases with the increasing of consolidation pressure for both horizontal and vertical planes. We observed that big aggregates gradually break into two or more aggregates.

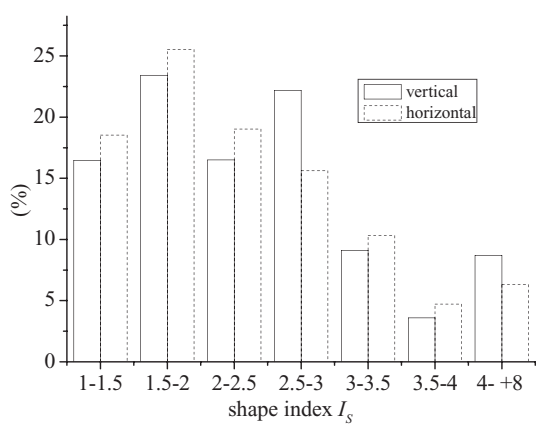

(a) $0 \mathrm{kPa}$

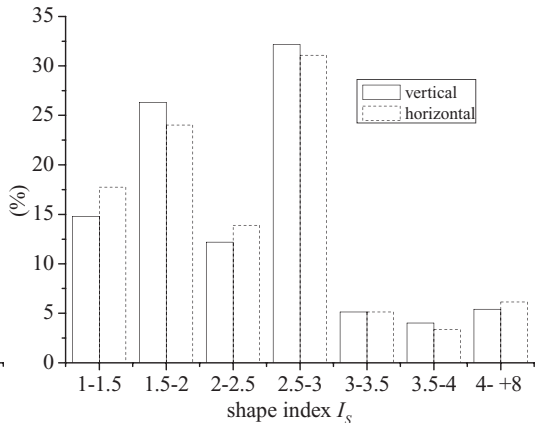

(b) $264 \mathrm{kPa}$

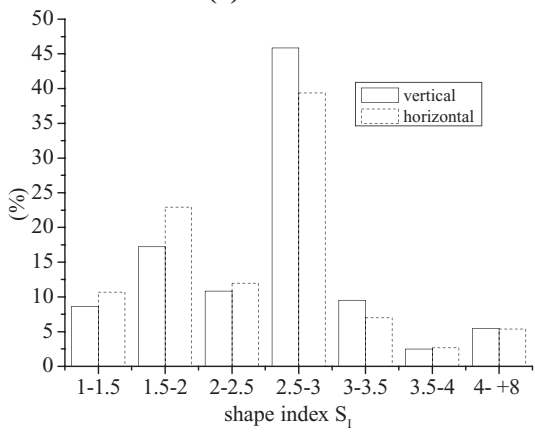

(c) $800 \mathrm{kPa}$

Figure 4. Shape index histograms of aggregate of Shanghai remolded clay under different consolidation pressure. 


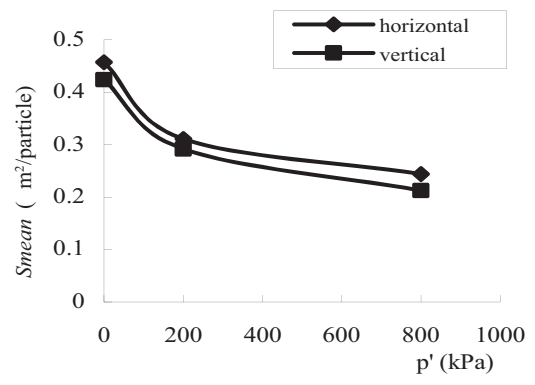

Figure 5. Mean area of particles under different consolidation pressure.

\section{CONCLUSION}

SEM photos show that the aggregate of Shanghai remolded clay is likely ellipse-sphere shape for both horizontal plane and vertical plane. Under the one-dimensional compression, the shape of aggregate changes more obviously for vertical plane rather than for horizontal plane. The one-dimensional compression results in a more orientated microstructure in the vertical plane rather than in the horizontal plane. The increase in direction frequency due to loading is mainly the results of aggregates breakage, with smaller aggregates easier orientated to the loading direction. Comparisons between SEM photos demonstrate that the Shanghai remolded clay has the characters of gradual damage, inherent and induced anisotropy during one-dimensional compression.

\section{REFERENCES}

Hicher PY, Wahyudi H, Tessier D (2000). Microstructural analysis of inherent and induced anisotropy in clay. Mechanics of Cohesive Frictional Materials 5: 341-371.

Kong LR, Huang HW, Hicher PY, Zhang DM (2008). The microstructure property on Shanghai mucky clay and its structural evolution during one dimensional consolidation test [J]. Chinese Rock and Soil Mechanics, 129(12): 3287-3292.

Martin JC, Ladd CC (1975). Fabric of consolidated kaolinite. Clay and Clay Mineral, 23(1): 17-25.

Matsuo S, Kamon M (1977). Microscopic study on deformation and strength of clays. 9th ICSMFE, the Japanese Society of Soil Mechanics and Foundation Engineering, Tokyo: 1: 201-204.

Mcconnachie I (1974). Fabric changes in consolidated kaolin. Geotechnique, 24(2): 207-222. 